\title{
Identifikasi dan model ruang terbuka hijau sebagai ruang evakuasi bencana alam gempa bumi berbasis SIG di kawasan Sanur, Denpasar, Bali
}

\author{
Nadiyah Rashifah ${ }^{1}$, Indayati Lanya2*, Ni Wayan Febriana Utami1 \\ 1. Program Studi Arsitektur Pertamanan, Fakultas Pertanian, Universitas Udayana, Indonesia \\ 2. Program Studi Agroekoteknologi, Fakultas Pertanian, Universitas Udayana, Indonesia \\ *E-mail: indahnet@yahoo.co.id
}

\begin{abstract}
Identification and model on green open space as evacuation area of earthquake at Sanur, South Denpasar, Bali. Bali Island is one of Indonesia's seismotectonics as it is passed through the Mediterranean mountain range and the subduction zone between the Eurasian Plate and the Indo-Australian Plate. The southern area of Bali is vulnerable to earthquake and one of the most vulnerable to the earthquake is Sanur. Sanur area has an area of $10,57 \mathrm{~km}^{2}$ or 1.057 hectares with a population of 28.527 inhabitants. Therefore, earthquake mitigation such as physical mitigation is to utilize green open space as an evacuation area is considered to be important. The purpose of this research is to identify the suitability of green open space as an evacuation area and to determine the green evacuation open space concept model. This research used satellite image interpretation and field survey methode. The data used is data of the earthquake center point throughout in Sanur along with potential tsunami risk map, green open space map and accessibility map. The parameters used were green open space width of at least $500 \mathrm{~m}^{2}$, types of green open space, accessibility, and potential earthquake and tsunami. Result showed that the green open space which suitable as an evacuation area was about 292 hectar and not suitable is 93 hectar. Furtheremore, the suitable green open space evacuation map was generated into two evacuation space concept. There were micro evacuation space and macro evacuation space. The micro evacuation space focuses on individual rescue while the macro evacuation space focuses on mass rescue.
\end{abstract}

Keywords: green open space, evacuation area, earthquake, Sanur area

\section{Pendahuluan}

\section{$1.1 \quad$ Latar Belakang}

Indonesia adalah wilayah kepulauan yang dilalui oleh lempeng samudera Eurasia, Pasifik - Hindia serta lempeng samudera Indo - Australia. Pulau Bali menjadi salah satu seismotektonik Indonesia karena daerah ini dilalui jalur pegunungan Mediteranian dan adanya zona subduksi akibat pertemuan antara Lempeng Eurasia dan Lempeng Indo-Australia. Berdasarkan sejarah selama periode 1953-2017, di daerah Bali sudah terjadi beberapa kali gempa bumi dengan magnitudo di atas 6,8 Skala Richter. Catatan kegempaan menunjukkan peristiwa gempa bumi kuat di Bali, yaitu gempa bumi 30 Juli $1968 \mathrm{M}$ sebesar 7,2 SR, gempa bumi 13 April 1985 M sebesar 6,8 SR dan gempa bumi 13 Oktober 2011 M sebesar 6,8 SR (Badan Meteorologi, Klimatologi dan Geofisika, 2017).

Daerah selatan Bali termasuk dalam daerah zona rawan gempa bumi dan salah satu kawasan yang rentan terhadap dampak bencana gempa bumi tersebut adalah kawasan Sanur. Kawasan ini memiliki potensi bencana gempa bumi yang sangat tinggi. Oleh sebab itu perlu dilakukan penanggulangan bencana alam khususnya gempa bumi di kawasan Sanur. Salah satu penanggulanagan bencana alam secara fisik yang bisa dilakukan adalah pemanfaatan ruang terbuka hijau (RTH) sebagai ruang evakuasi bencana alam gempa bumi.

Kawasan Sanur dengan luas wilayah total sebesar 10,57 km² atau 1.057 hektar dan indeks kepadatan penduduk sebesar 6891 jiwa/km² memiliki kepadatan masing-masing untuk wilayah Desa Sanur Kauh sebesar 2.844 jiwa/km², Desa Sanur Kaja sebesar 2.931 jiwa $/ \mathrm{km}^{2}$ dan Kelurahan Sanur sebesar 2.402 jiwa/km² (Badan Pusat Statistik Denpasar 2017). Dengan kerentanan wilayah ini terhadap bencana alam gempa bumi disertai dengan kepadatan penduduk yang tinggi dan kurangnya RTH menyebabkan perlu adanya ruang evakuasi bencana yang memadai. Oleh sebab itu, diperlukan rencana ruang evakuasi yang memadai untuk memfasilitasi keselamatan masyarakat kawasan Sanur. Berdasarkan latar belakang tersebut, dapat ditarik 
rumusan masalah yaitu untuk melihat bagaimana kesesuaian dan model RTH sebagai ruang evakuasi bencana alam gempa bumi di kawasan Sanur. Selanjutnya, penelitian ini ditujukan untuk mengidentifikasi kesesuaian RTH sebagai ruang evakuasi bencana alam gempa bumi di kawasan Sanur sehingga peluang untuk proses evakuasi dapat lebih mudah dan tidak memakan banyak korban jiwa.

\section{Metode Penelitian}

\subsection{Waktu dan Tempat Penelitian}

Penelitian identifikasi kesesuaian RTH sebagai ruang evakuasi bencana alam gempa bumi dimulai bulan Januari hingga Juli 2018 di kawasan Sanur, Denpasar Selatan, Provinsi Bali. Luas kawasan yang dijadikan sebagai lokasi penelitian sebesar $10,57 \mathrm{~km}^{2}$ yang meliputi tiga wilayah Desa dan Kelurahan yaitu Desa Sanur Kaja, Desa Sanur Kauh dan Kelurahan Sanur (Gambar 2).

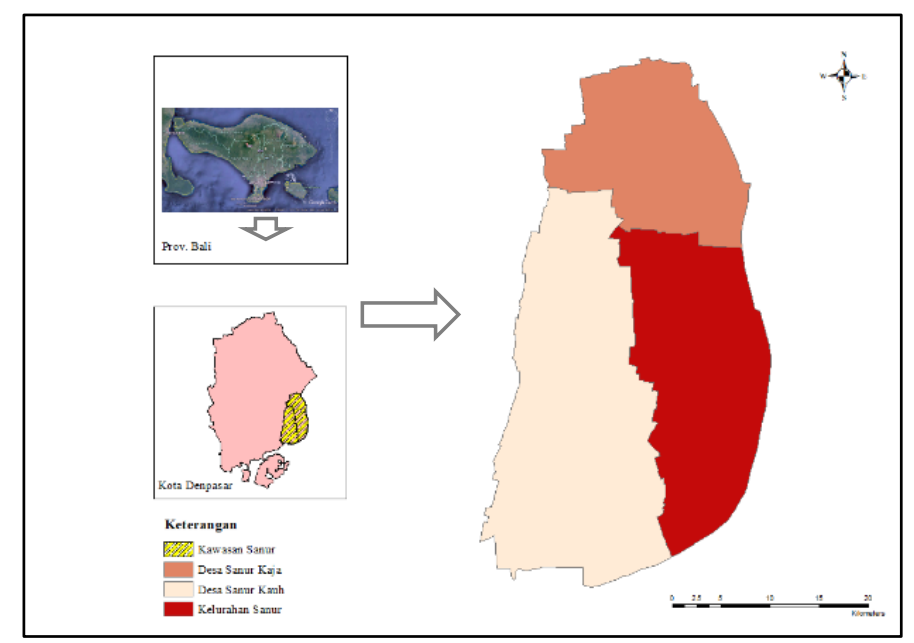

Gambar 2. Lokasi Penelitian (Sumber google earth dan Bappeda 2017)

\subsection{Alat dan Bahan}

Alat dan bahan yang digunakan dalam penelitian ini antara lain peta kawasan Sanur baik itu peta penggunaan lahan, peta geologi, peta sirkulasi dan aksesibilitas, peta topografi serta perangkat keras (hardware) GPS dan perangkat lunak (software) seperti software ArcGIS, Photoshop, Ms Word selain peralatan lainnya seperti kamera digital dan alat tulis.

\subsection{Metode penelitian}

Penelitian dilaksanakan menggunakan metode survey lapang dan interpretasi citra satelit. Terdapat tiga tahapan dalam penelitian (Gambar 3): tahap pertama meliputi persiapan dan pengumpulan data; tahap kedua yaitu tahap analisis dan sintesis dengan hasil berupa identifikasi RTH, jenis dan luasan RTH serta potensi bencana gempa bumi dan tsunami; dan tahap terkhir yaitu tahap pembuatan model RTH evakuasi.

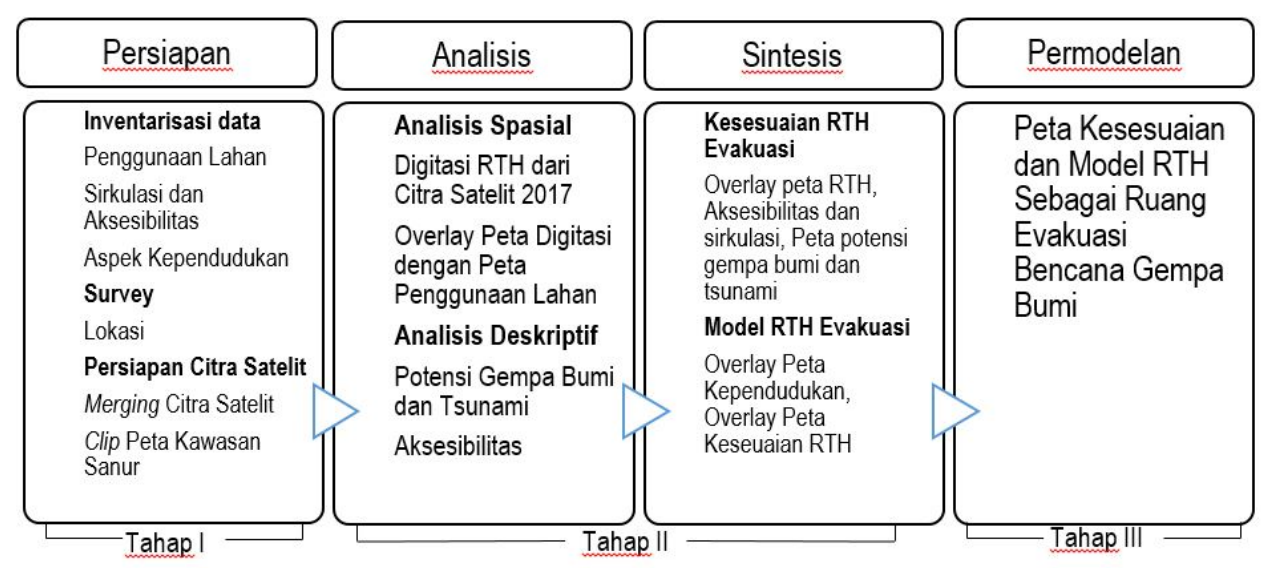

Gambar 3. Tahapan Penelitian 


\subsection{Data Penelitian}

Data penelitian merupakan data fisik kawasan, merupakan data primer yang didapat dari interpretasi citra satelit dan survey lapang. Data sekunder yang didapat dari studi kepustakaan dan sumber-sumber lainnya. Seperti data letak geografis dan administrasi kawasan Sanur, penggunaan lahan, data geologi, topografi, aksesibilitas dan sirkulasi, sarana dan prasarana, serta data aspek kependudukan meliputi jumlah penduduk. Selanjutnya data dikelompokan mejadi data biofisik dan data sosial.

\subsection{Ruang Lingkup Penelitian}

Lokasi Penelitian dilakukan di kawasan Sanur dengan metode penelitian adalah survey lapang dan interpretasi citra satelit. Pengumpulan data dilakukan dengan pendekatan secara aktif baik dari segi sumber daya maupun dari segi aktivitas pada tapak. Tahap-tahap proses penelitian dimulai dari persiapan, analisis data, sintesis, model RTH evakusi dan outputnya berupa peta RTH yang sesuai untuk ruang evakuasi bencana gempa bumi serta model RTH evakuasi.

\section{Hasil dan Pembahasan \\ 3.1 Kondisi Umum Kawasan \\ 3.1.1 Aspek Biofisik}

Secara geografis, kawasan Sanur berada pada koordinat $8^{\circ} 38^{\prime} 00^{\prime \prime}$ dan $08^{\circ} 42^{\prime} 30^{\prime \prime} \mathrm{LS}, 115^{\circ} 16^{\prime} 30^{\prime \prime}$ BT. Kawasan Sanur terdiri dari Desa Sanur Kaja, Desa Sanur Kauh dan Kelurahan Sanur. Luas wilayah total Kawasan Sanur 10,57 km². Sebelah selatan kawasan Sanur dilalui oleh lempang tektonik antara Lempeng tektonik Indo-Australia dengan Lempeng Eurasia. Pada daerah pesisir pantai sepanjang Pantai Matahari Terbit hingga Pantai Mertasari memiliki jenis tanah berupa batuan endapan laut yang bersifat lepas. Sedangkan pada daerah bagian utara dan barat kawasan Sanur ditemukan bahan volkan berupa tuff dan endapan lahar Buyan, Baratan dan Batur. Kondisi topografi kawasan Sanur datar, elevasi tertinggi daerah ini \pm 7 meter dengan kemiringan lereng antara $0 \%-2 \%$.

Penggunaan lahan yang dominan berupa pemukiman yang mencapai luasan $5,3 \mathrm{~km}^{2}$ atau setara dengan 50,6\% dari luasan kawasan Sanur. Penggunaan lahan lainnya yaitu sebagai tegalan seluas 2,12 km² atau setara dengan $20,1 \%$ dan kebun seluas $1,64 \mathrm{~km}^{2}$ atau 15,6\%. Penggunaan lahan ini berpusat di wilayah Sanur Kauh dan sedikit di Sanur Kaja. Sisa penggunaan lahan berupa persawahan seluas 1,10 $\mathrm{km}^{2}$ atau 10,5\% dan hutan mangrove seluas $0,33 \mathrm{~km}^{2}$ atau setara dengan $3,2 \%$.

Terdapat empat jenis jalan yang ada di kawasan Sanur yaitu jalan provinsi, jalan nasional, jalan kota dan jalan lingkungan. Fasilitas yang berkaitan dengan mitigasi bencana tsunami di kawsan Sanur antara lain peta jalur evakuasi, peta kawasan bahaya tsunami dan papan petunjuk jalur evakuasi di beberapa titik wilayah terutama di wilayah Kelurahan Sanur yang merupakan pusat pariwisata.

\subsubsection{Aspek Kependudukan}

Jumlah penduduk di kawasan Sanur hingga akhir tahun 2015 adalah 28.527 jiwa dengan jumlah penduduk masing-masing wilayah yaitu Sanur Kaja sebanyak 7.886 Jiwa, Sanur Kauh 10.981 Jiwa, dan Sanur sebanyak 9.660 jiwa. Sanur kaja menjadi wilayah dengan tingkat kepadatan tertinggi dibanding wilayah sanur lainnya sebesar $2.931 \mathrm{jiwa/} \mathrm{km²}$. Selanjutnya wilayah Sanur Kauh memiliki tingkat kepadatan penduduk sebesar 2.844 jiwa/ km² disusul Wilayah Sanur sebesar 2.402 jiwa/ km².

\subsection{Analisis}

\subsubsection{Identifikasi RTH}

Identifikasi ruang terbuka hijau dilakukan untuk melihat persebaran RTH dalam kawasan Sanur dan melihat potensi RTH tersebut sebagai ruang evakuasi gempa bumi. RTH didentifikasikan melalu digitasi citra satelit 2017 serta sumber penggunaan lahan dari Bappeda 2017. Berdasarkan proses digitasi, didapatkan sebaran RTH pada setiap Desa di Sanur yang dibagi berdasarkan jenisnya yaitu: sawah, lapangan olah raga, area terbuka, hutan dan hutan mangrove. Pada Gambar 4 terlihat sebaran RTH paling banyak terdapat di Desa Sanur Kaja seluas 2,21 km². Sedangkan Desa Sanur menempati urutan terakhir dalam luasan RTH seluas $0,49 \mathrm{~km}^{2}$ dan Desa Sanur Kauh sebesar $0,96 \mathrm{~km}^{2}$. Hasil identifikasi ini selanjutnya akan di-overlay dengan peta potensi gempa bumi, tsunami dan peta aksesibilitas untuk menentukan RTH yang sesuai sebagai ruang evakuasi. 


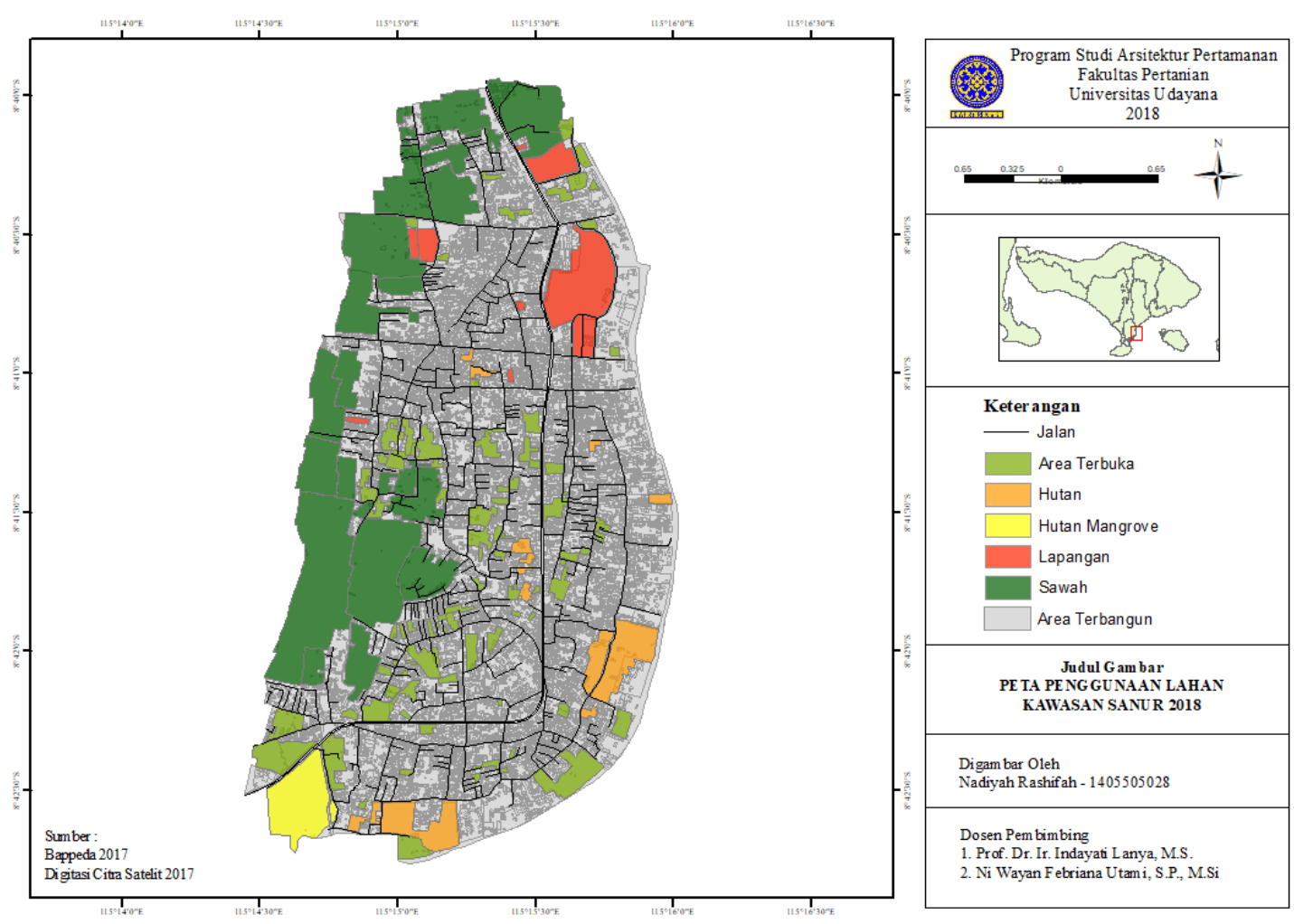

Gambar 4. Peta Pengguanan Lahan di Kawasan Sanur

\subsubsection{Aspek Kebencanaan}

Seperti yang terlihat pada Gambar 5 a, Kawasan Sanur yang termasuk zona merah dalam peta bahaya gempa bumi mengartikan bahwa kawasan Sanur memiliki potensi gempa bumi yang cukup tinggi. Titik gempa yang biasanya terjadi di Kawasan Sanur berada pada dasar laut yang bersumber dari patahan lempang IndoAustralia dengan Eurasia serta Lempeng Pasifik. Sumber gempa bawah laut ini yang memiliki korelasi dengan potensi bahaya bencana tsunami. Karena itu, kawasan Sanur juga termasuk dalam kawasan rawan Tsunami. Peta indeks resiko bencana tsunami (Gambar 5 b), menunjukan bahwa kawasan Sanur termasuk dalam zona tinggi potensi tsunami. Berdasarkan penelitian Bayu Baskara 2017, sepanjang garis pantai Bali bagian selatan, memiliki potensi dampak terbesar jika terjadi tsunami. Termasuk sepanjang pesisir pantai sanur yang berbatasan langsung dengan laut selatan Bali. Untuk lebih jelasnya bisa dilihat di Tabel 2.

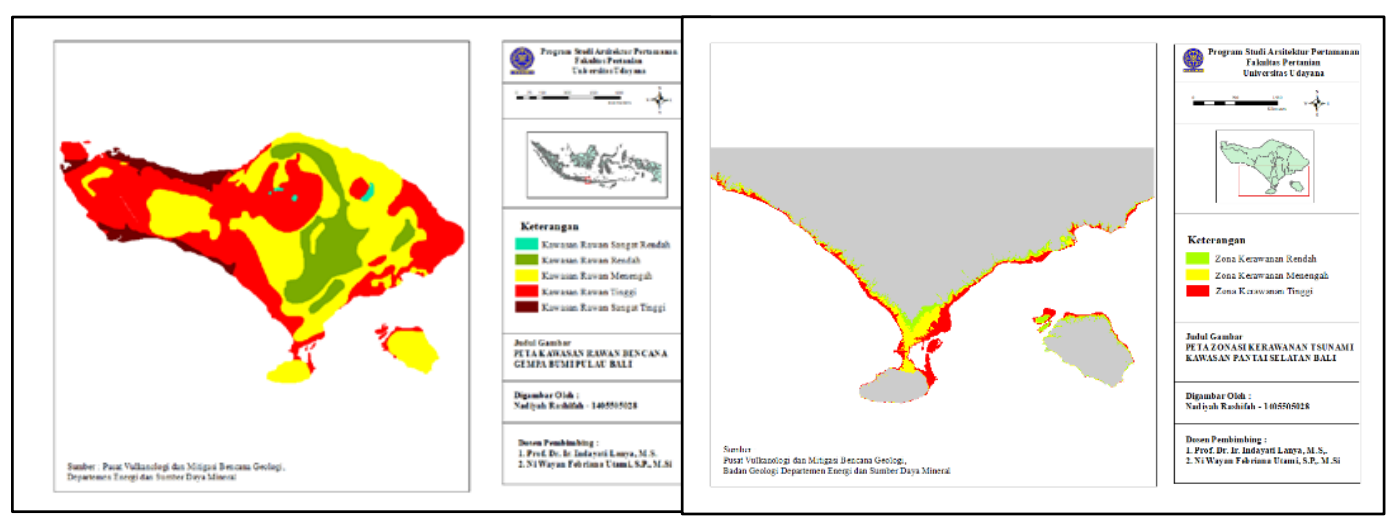

a. Peta Resiko Bencana Gempa Bumi Prov. Bali b. Peta Resiko Bencana Tsunami Prov. Bali Gambar 5. Peta Indeks Resiko Kebencanaan Provinsi Bali 
Sumber titik gempa kawasan Sanur berada pada bagian selatan dari kawasan Sanur. Sumber titik gempa ini juga menambah potensi resiko bencana tsunami terlebih jika terjadi gempa bumi dangkal berkekuatan lebih dari 5 Skala richter dengan kedalaman kurang dari $60 \mathrm{Km}$. Jika terjadi gempa dalam, dengan kedalaman 70 - $300 \mathrm{Km}$, maka tidak menimbulkan tsunami sebab gempa dalam tidak menyebabkan dislokasi yang berarti di permukaan.

Tabel 2. Analisis Aspek Kebencanaan kawasan Sanur

\begin{tabular}{lll}
\hline \multicolumn{1}{c}{ Data } & \multicolumn{1}{c}{ Kondisi } & \multicolumn{1}{c}{ Analisis } \\
\hline Gempa bumi & $\begin{array}{l}\text { Terdapat sumber titik gempa bumi di } \\
\text { pulau Bali bagian selatan. }\end{array}$ & $\begin{array}{l}\text { Diperlukan pemanfaatan ruang } \\
\text { terbuka hijau sebagai ruang } \\
\text { Sanur termasuk daerah rawan gempa } \\
\text { bumi (BMKG, 2017). }\end{array}$ \\
& $\begin{array}{l}\text { Sumber gempa bumi bawah laut } \\
\text { disepanjang sesar selatan berpotensi }\end{array}$ & berdekatan dengan evakuasi \\
& $\begin{array}{l}\text { menimbulkan tsunami. } \\
\text { kawasan Sanur termasuk zona merah } \\
\text { rawan tsunami (ESDM, 2017) }\end{array}$ & $\begin{array}{l}\text { vertikal tsunami seminga } \\
\text { bumi disusul tsunami. }\end{array}$ \\
\hline
\end{tabular}

\subsection{Sintesis}

Hasil analisis secara menyeluruh dari berbagai aspek terkait identifikasi dan permodelan konser RTH evakuasi, diketahuilah bahwa kawasan Sanur memiliki potensi bencana alam gema bumi. Hasil analisis tersebut menunjukan adanya potensi pergerakan lempeng dan potensi bahaya lainnya yang dapat mengancam keselamatan masyarakat kawasan Sanur. Bahaya lainnya yaitu, gempa bumi yang terjadi di kawasan Sanur memiliki korelasi dengan potensi bencana Tsunami karena potesi titik gempa yang sering terjadi di dalam laut.

Ditinjau dari analisis tersebut, sebaiknya dilakukan upaya penanggulangan bencana gempa bumi di kawasan Sanur. Dalam tahapan sintesis ini, penanggulangan yang dilakukan berupa penentuan zona RTH yang sesuai terhadap ruang evakuasi. Penentuan zona yang ada dilakukan melalui overlay peta jenis RTH, peta potensi bencana gempa bumi dan tsunami. Overlay peta ini menghasilkan zona sesuai, dan tidak sesuai untuk kawasan evakuasi yang divisualisasikan pada Gambar 6.

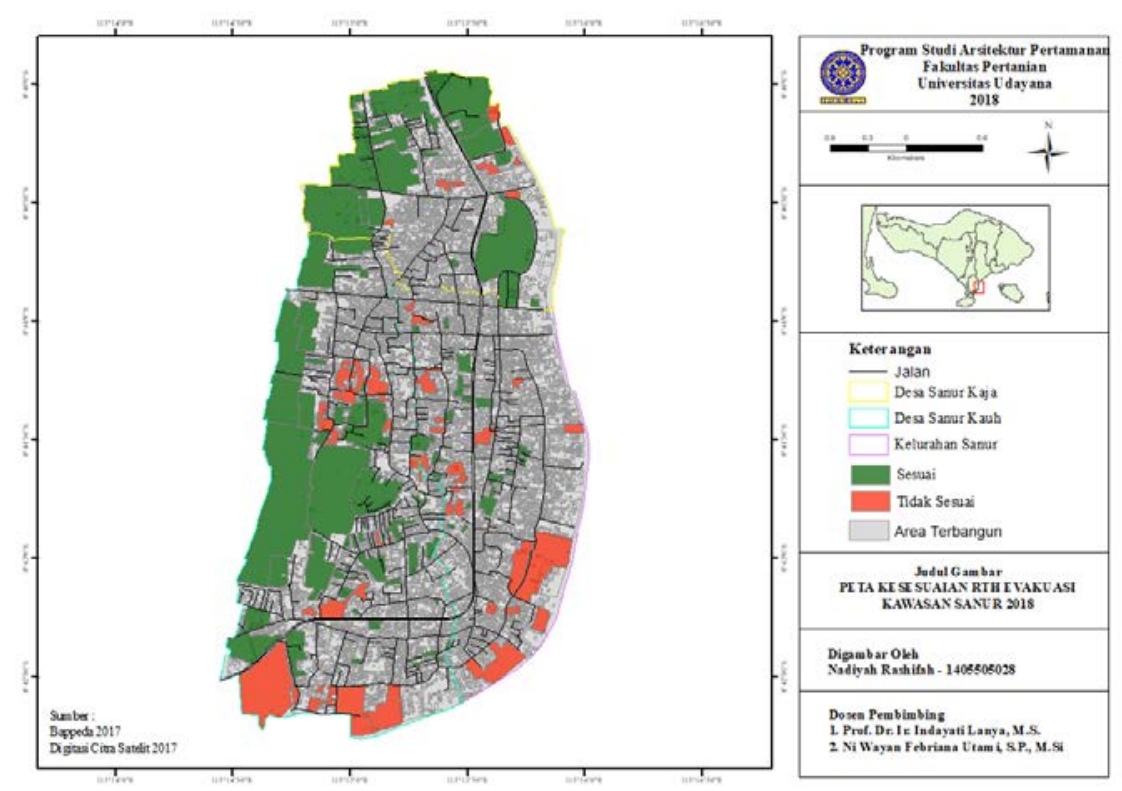

Gambar 6. Peta Kesesuaian RTH Evakuasi Kawasan Sanur 
Hasil overlay seperti pada Gambar 6 didapatkan RTH yang sesuai sebagai ruang evakuasi sebesar 292 hektar yang terdiri dari lapangan olah raga, sawah dan beberapa area terbuka. Sedangkan RTH yang tidak sesuai sebesar 93 hektar yang terdiri dari area terbuka berupa semak belukar, hutan mangrove, hutan dan beberapa RTH yang terdapat di pesisir pantai.

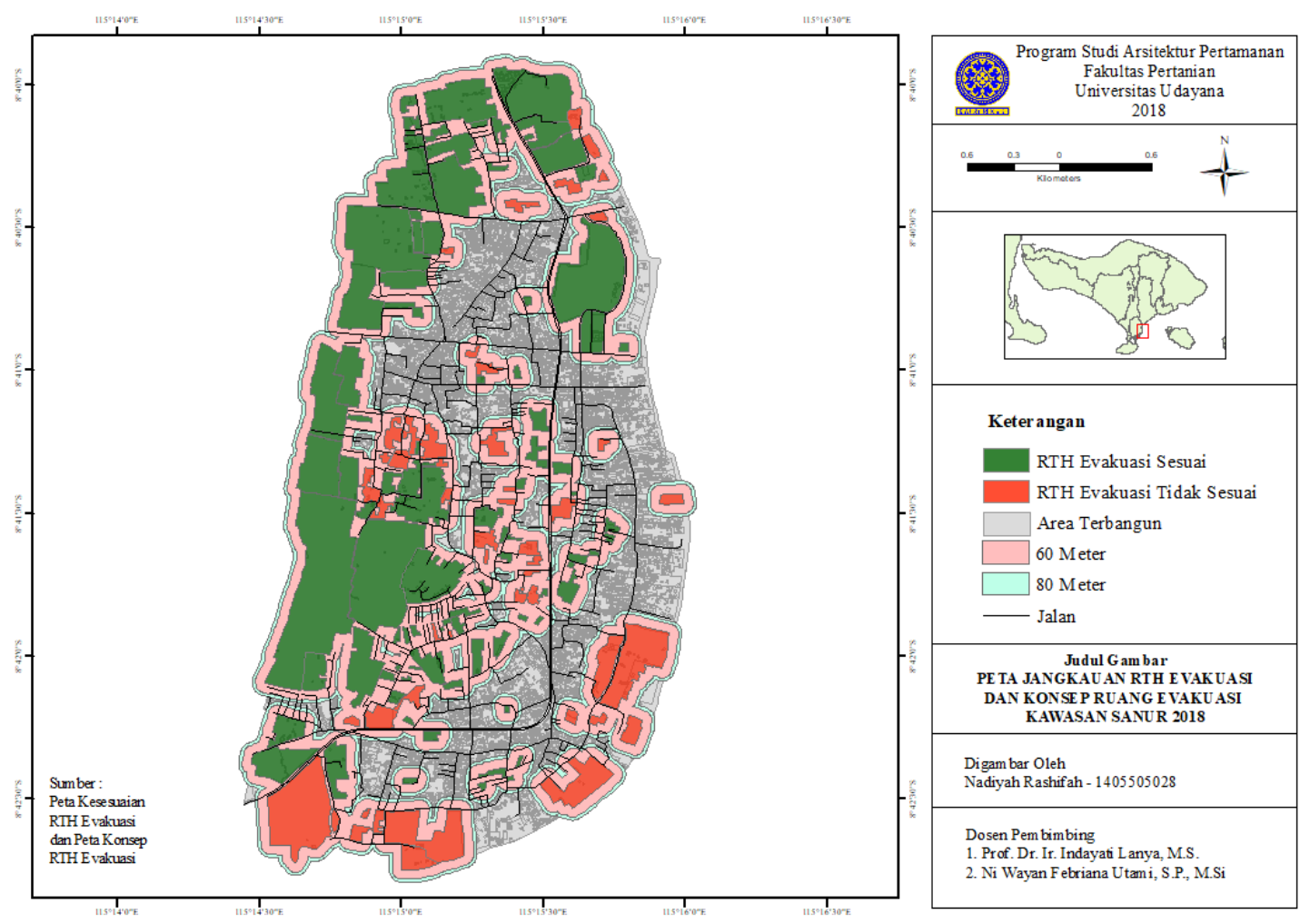

Gambar 7. Peta Jangkauan RTH Evakuasi

Pada penelitian ini digunakan asumsi dua jarak berdasarkan penelitian Sagala 2013 karena asumsinya reaksi setiap orang berbeda dalam menghadapi gempa. Sehingga untuk melihat jangkauan dari RTH evakuasi yang ada dilakukan buffering menggunakan ArcGIS dengan parameter jangkauan pelayanan ruang evakuasi minimal adalah antara 60 - 80 meter. Gambar 7 menunjukan jangkauan RTH evakuasi dari radius $60 \mathrm{~m}$ dan $80 \mathrm{~m}$. Hal ini memperlihatkan tidak semua wilayah terjangkau RTH evakuasi yang ada baik itu dalam jangkauan $60 \mathrm{~m}$ atau $80 \mathrm{~m}$.

Kebutuhan ruang evakuasi dapat dilihat dari standar bergerak orang dewasa yaitu 2,52 $\mathrm{m}^{2}$ (Keputusan Menteri Pekerjaan Umum RI No 468/KPTS/1998) dan jumlah penduduk kawasan Sanur yaitu 28.527 jiwa. Berdasarkan hal tersebut, ruang evakuasi yang dibutuhkan untuk menampung penduduk kawasan Sanur sebesar $71.888,04 \mathrm{~m}^{2}$ atau 0,0718 $\mathrm{km}^{2}$. RTH evakuasi yang ada sebesar $2,92 \mathrm{~km}^{2}$, maka kapasitas RTH evakuasi kawasan Sanur telah terpenuhi. Namun hal ini tidak dibarengi dengan lokasi RTH evakuasi yang belum menjangkau seluruh kawasan Sanur sehingga persebaran RTH evakuasi tidak merata.

\subsection{Model RTH Sebagai Ruang Evakuasi Bencana Gempa Bumi}

Pembagian zona model RTH evakuasi didasarkan pada keadaan sosial dan geografis yang ada, serta beberapa pertimbangan seperti pembagian sesuai kluster dalam prosedur mitigasi bencana alam. Model ini diterapkan dengan fungsi dari RTH tersebut sebagai ruang evakuasi yang diidentifikasikan untuk mempermudah proses evakuasi atau penyelamatan diri sendiri serta dapat meminimalkan korban jiwa saat terjadi bencana gempa bumi. Model RTH ini juga mempertimbangakan jalur evakuasi dan zona evakuasi bencana tsunami yang telah direncanakan oleh pemerintah Provinsi Bali pada tahun 2010. Penerapan ruang evakuasi makro dan mikro didasarkan pada tata ruang kota kawasan Sanur, jumlah penduduk dan kepadatan penduduk. 
Berdasarkan hasil sintesis dan proses penilaian kesesuaian lahan untuk evakuasi, maka RTH sebagai ruang evakuasi dibagi menjadi:

1. Ruang Evakuasi Mikro

Ruang evakuasi mikro merupakan ruang yang pertama kali akan berperan secara langsung terhadap masyarakat saat terjadi bencana gempa bumi. Memiliki ciri-ciri berada di tengah pemukiman penduduk, luas RTH lebih kecil dari ruang evakuasi makro dan jenis RTH berupa area terbuka. Salah satu aspek keselamatan yang jadi perhatian yaitu kemudahan aksesibilitas untuk mencapai ruang mikro ini. Fokus penyelamatan pada ruang evakuasi mikro yaitu penyelamatan secara individu. Ruang terbuka hijau mikro ini dapat dijadikan sebagai shelter sementara bagi para pengungsi. Contoh RTH evakuasi mikro dapat dilihat di Gambar 8. Gambar 8 b mempertlihatkan ruang evakuasi mikro yang terdapat di Jalan Tirta Ening II, Sanur Kauh. RTH ini berada di pinggir jalan yang berbatasan langsung dengan rumah padat penduduk.

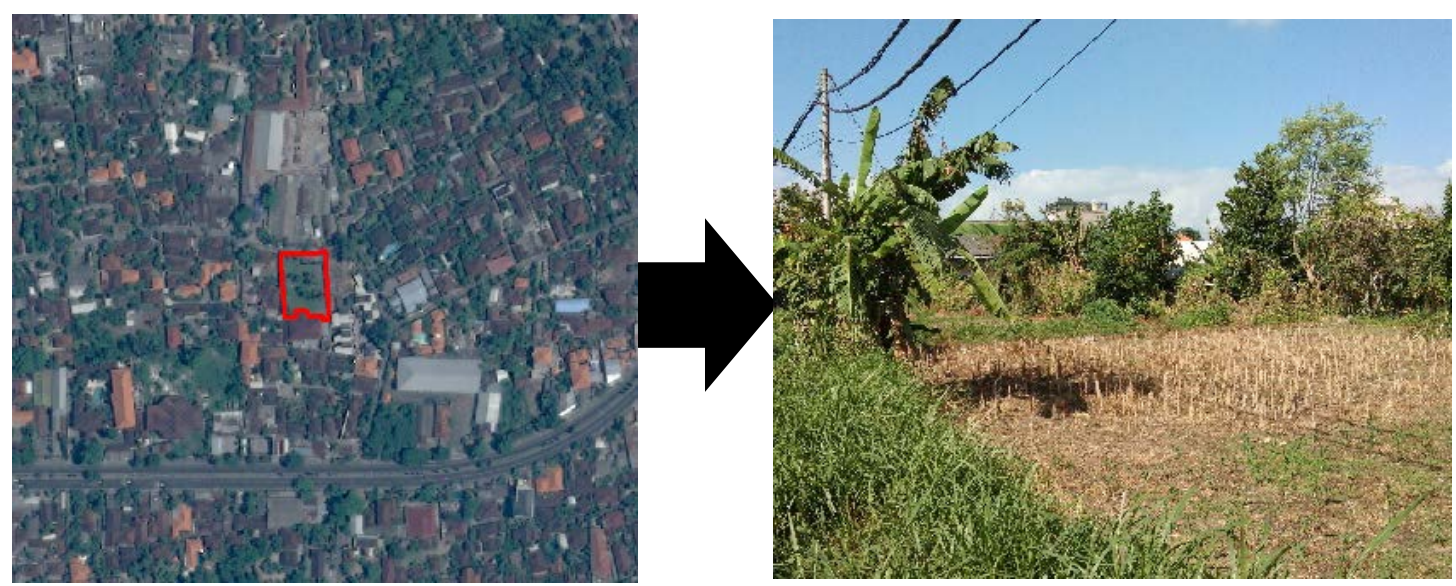

a. RTH Evakuasi mikro dalam citra satelit

b. RTH Evakuasi Mlkro

Gambar 8. Contoh RTH Evakuasi Mikro

\section{Ruang Evakuasi Makro}

Pada ruang evakuasi makro, fokus penyelamatan lebih bersifat masal. Masing-masing desa memiliki ruang evakuasi makro yang dapat menampung warga desa tersebut. Ciri-ciri ruang ini memiliki luas ruang evakuasi lebih besar dari ruang evakuasi mikro, lokasinya mengelilingi ruang evakausi makro dan jenis RTH evakuasi berupa sawah, area terbuka, lapangan olah raga. Ruang ini dapat berfungsi sebagai shalter utama dan titik kumpul para pengungsi. Selain itu dalam ruang ini terdapat kluster-kluster yang memfasilitasi pengungsi seperti kluster sosial, kluster kesehatan dan kluster penyelamatan. Bencana gempa bumi yang memakan banyak korban, ruang evakuasi makro juga dapat berfugsi sebagai ruang pemakaman masal seperti pada kasus gempa bumi di Padang dan tsunami di Aceh.

RTH evakuasi makro memiliki bentuk yang lebih luas dari pada RTH evakuasi mikro. Hal ini disebabkan dari pertimbangan bahwa RTH evakuasi makro harus dapat menampung masayarakat secara masal. Contoh dari RTH evakuasi makro dapat dilihat di Gambar 9.b. RTH ini berupa area terbuka yang berlokasi di Jalan Tukad Nyali, Sanur Kauh dan berada di pinggir wilayah pemukiman padat penduduk. 


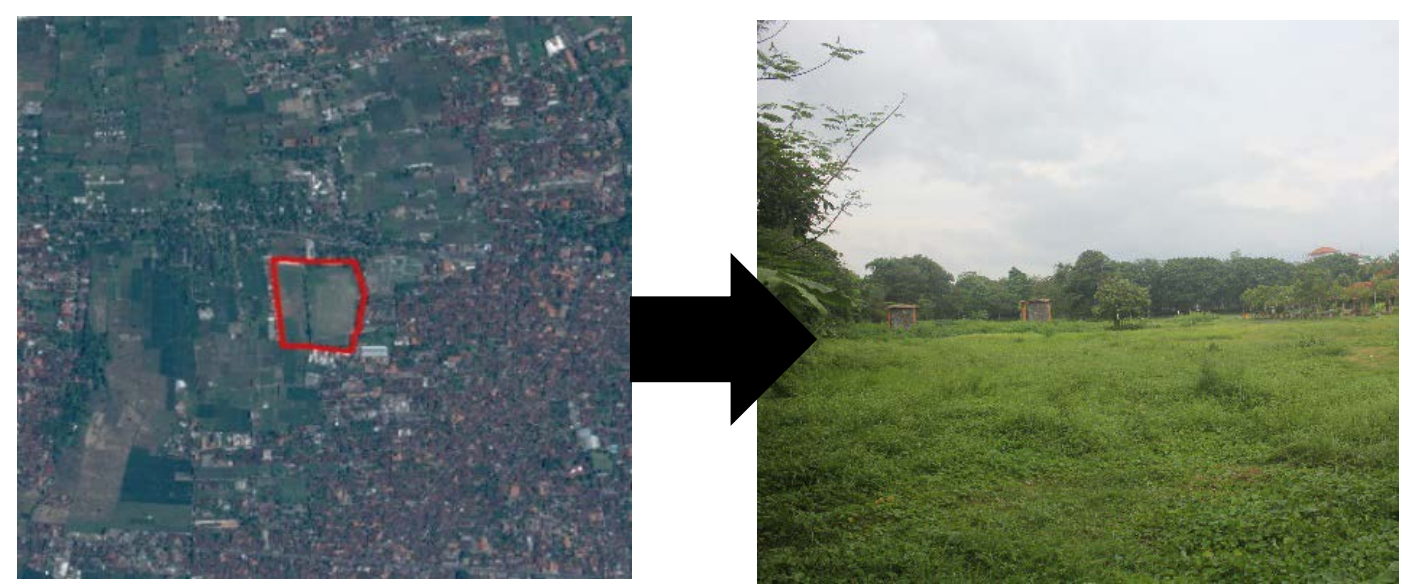

a.RTH Evakuasi makro terlihat dari citra satelit

b. RTH Evakuasi Makro

Gambar 9. Contoh RTH Evakuasi Makro

Gambar 10 memperlihatkan peta RTH evakuasi dengan konsep RTH evakuasi makro dan mikro (Gambar 10.a) dan hasil overlay dari peta kesesuaian RTH evakuasi dengan peta konsep RTH evakuasi (Gambar 10.b). Secara umum dapat dijelaskan bahwa terdapat beberapa RTH evakuasi makro yang berada di sepanjang garis pantai yang dikategorikan tidak sesuai digunakan sebagai RTH evakausi. Hal ini disebabkan oleh adanya potensi tsunami di kawasan Sanur tidak memungkinkan semua titik menjadi tempat evakuasi secara massal. Sebaliknya, kawasan yang lebih sesuai untuk evakuasi makro dan beberapa ruang evakuasi mikro (tersebar secara acak) terdapat di bagian dalam kawasan (menjauhi laut).

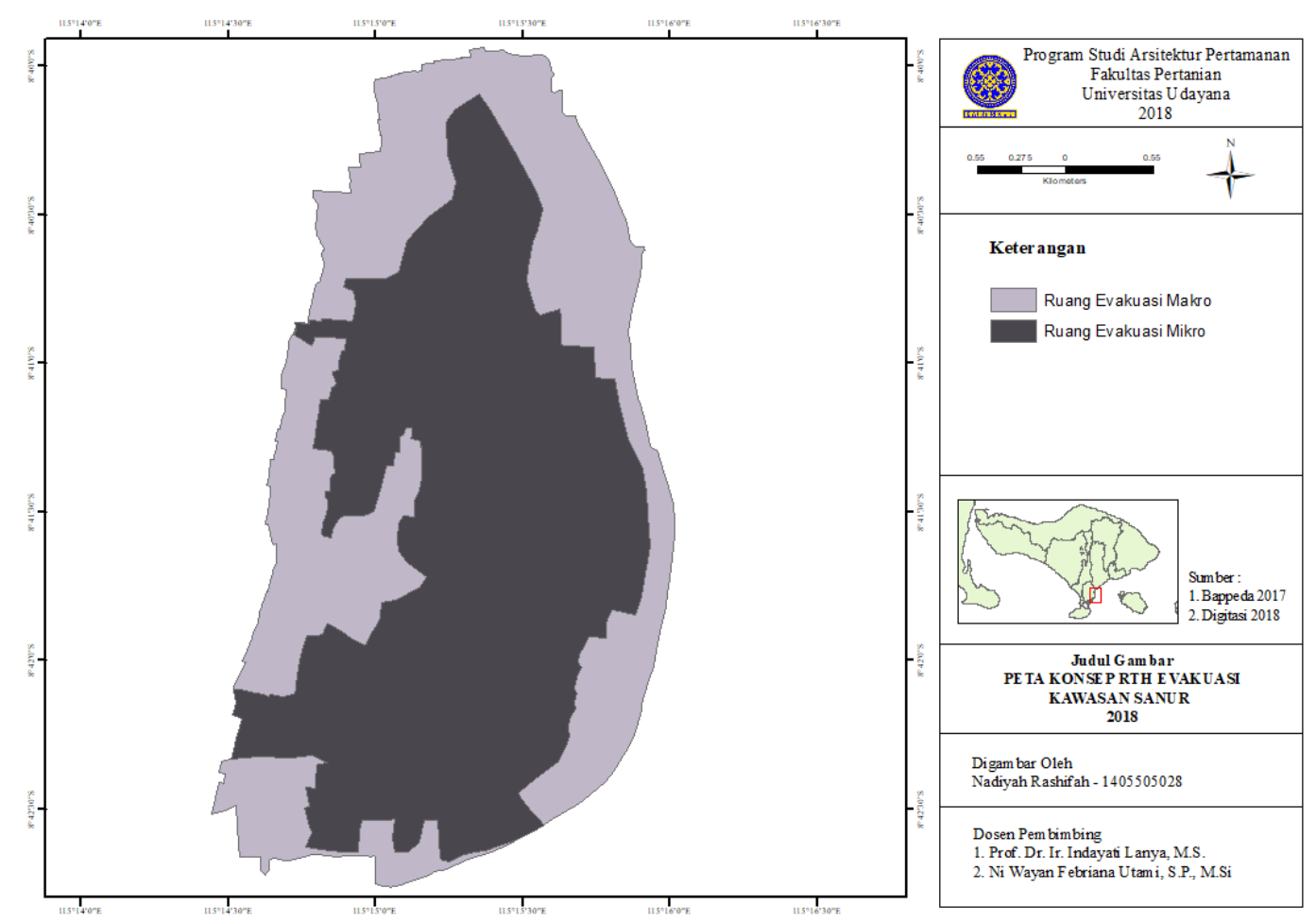

10a. Peta Konsep RTH evakuasi 


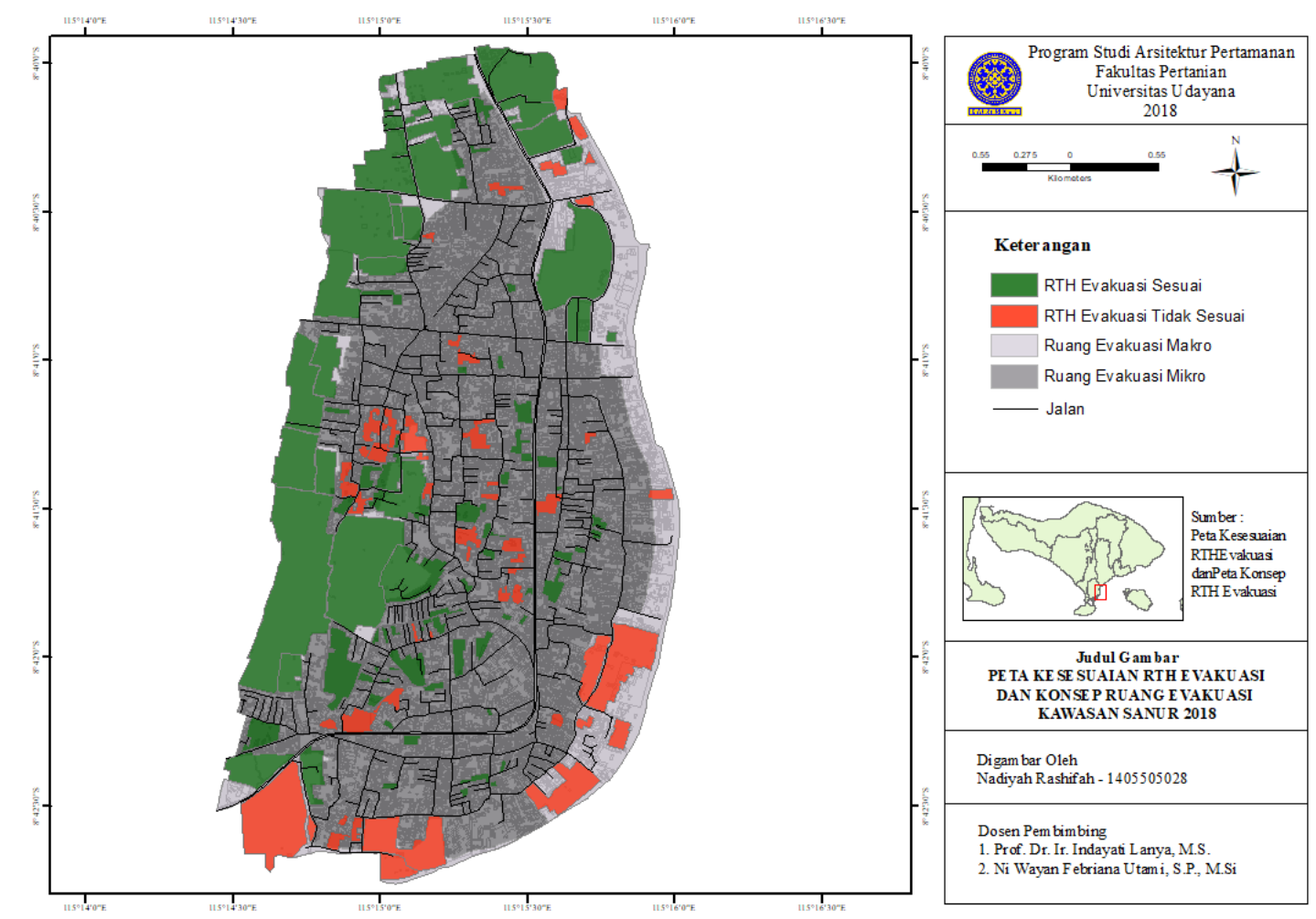

10b. Peta Konsep dan Kesesuaian RTH Evakuasi

\section{Simpulan dan Saran \\ 4.1 Simpulan}

Berdasarkan penelitian ini dapat ditarik kesimpulan bahwa RTH pada Kawasan Sanur dapat dijadikan sebagai ruang evakuasi bencana gempa bumi dengan jenis RTH antara lain sawah, lapangan olah raga, dan area terbuka. Lokasi pada area ini contohnya adalah lapangan Letda Made Pica, Lapangan Golf Grand Ina Bali Beach, area persawahan di Sanur Kaja dan Sanur Kauh. Kapasitas RTH sebagai ruang evakuasi sudah terpenuhi sebesar $2,92 \mathrm{~km}^{2}$ dan RTH yang tidak sesuai sebagai ruang evakuasi sebesar $0,93 \mathrm{~km}^{2}$. Namun sebaran RTH tersebut belum bisa menjangkau seluruh kawasan Sanur. Untuk zona evakuasi pada Kawasan Sanur dibagi menjadi dua model ruang yaitu zona ruang evakuasi mikro dan ruang evakuasi makro. Kedua model ruang ini memiliki fungsi sebagai ruang evakuasi, jalur penyelamatan, shelter sementara bagi para pengungsi, dan titik kumpul masyarakat. Kedua ruang ini dihubungkan oleh jalur evakuasi. Jalur evakuasi gempa bumi di kawasan Sanur menuju kearah barat yang menjauhi daerah pantai dengan mekanisme penyelamatan dimulai dari ruang evakuasi mikro yang sudah teridentifikasi kemudian menuju ruang evakuasi makro melalui jalur evakuasi terdekat.

\subsection{Saran}

Untuk pemanfaatan RTH di Kawasan Sanur sebagai ruang evakuasi gempa bumi memerlukan beberapa fasilitas yang dapat menunjang evakuasi tersebut. RTH evakuasi juga dapat dimanfaatkan sebagai pengendali ekosistem dan lingkungan. Dengan demikian, diharapkan pembangunan dan pengembangan wilayah kota berbasis mitigasi bencana dapat mengoptimalkan aktivitas masyarakat terutama dalam perlindungan dan penyelamatan diri. 


\section{Daftar Pustaka}

Baskara Bayu, Sukarsa, Septiadhi. 2017. Pemetaan Bahaya Gempa Bumi dan Potensi Tsunami di Bali Berdasarkan Nilai Seismistas. Buletin Fisika, 18(1):20-16

Badan Meteorologi Klimatologi dan Geofisika. 2017. Gempa Bumi. http://balai3.denpasar.bmkg.go.id/tentanggempa. (tersedia dalam jaringan pada 20 Maret 2017)

Badan Nasional Penanggulangan Bencana. 2017. Tanggap Tangkas Tangguh Menghadapi Bencana. BNPB, Jakarta

Badan Pusat Statistik Denpasar. 2017. Kepadatan Penduduk 2017. BPS, Bali

Kelompok Kerja Perencanaan Evakuasi Untuk Sanur. 2010. Rencana Evakuasi Tsunami Untuk Sanur. Denpasar

Kemenpu (Kementrian Pekerjaan Umum). 1998. Persyaratan Teknis Aksesibilitas pada Bangunan Umum dan Lingkungan. Mentri Pekerjaan Umum. Jakarta

Sagala Saut, Sari, Saraswati. 2013. Analisis Spasial Ketersediaan Ruang Terbuka Publik Pada Pemukiman Padat untuk Evakuasi Pada Gempa Susulan, Studi Kasus: Kelurahan Suhahaji Bandung. Forum Geografi, 27(2):123-134

Sucipto Daryono. 2010. Zona Rawan Gempa Daerah Bali: Tinjauan Seismisitas dan Data Historis. https://www.facebook.com/notes/wwwbmkggoid/zona-rawan-gempa-daerah-bali-tinjauan-seismisitasdan-data-historis-oleh-daryono/398395940788/ (tersedia dalam jaringan pada 20 Maret 2017) 